\title{
Self Blood with Betamethasone in Management of Rheumatoid Arthritis
}

\author{
Dr. Avinash Shankar \\ $\mathrm{MD}$ (internal Medicine);DNB(Endocrinology) \\ $\mathrm{DCH} ; \mathrm{PhD} ; \mathrm{FRCP}(\mathrm{G})$ Chairman \\ National Institute of Health \& research \\ Warisaliganj (Nawada), Bihar, India \\ Dr. Farhat Jabeen \\ Project Officer, Burn Management \\ RA.Hospital \& Research Centre, Warisaliganj \\ Presently Medical Officer, RBSK, Government of Bihar \\ PHC, Aliganj (Jamui), Bihar
}

\begin{abstract}
R A$ an auto immune disorder causing degenerative joint lesion for which anti arthritic analgesics, steroid and DMARDs are commonly used with an aim to improve pain, decrease inflammation and improve quality of life. Pain of RA is of nociceptive type than neuropathic and cure remain an existing challenge..

Thus in the present study 210 cases of non diabetic non hypertensive RA cases with poor to worse quality of life non responsive to conventional practiced therapeutics, a treatment module constituting Self blood $2 \mathrm{ml}$ with Inj Betamethasone $4 \mathrm{mg}$ (1ml) intramuscular every $4^{\text {th }}$ day, (Inj Calcium Sandoz (Calcium gluconate and Calcium lactobionate $) 10 \mathrm{ml}$ intravenous slowly every $15^{\text {th }}$ day, Inj Methyl cobalamine $1500 \mathrm{mcg}$ with Nicotinamide and pyridoxine 100mg each intravenous every week, Cap Vit $D_{3}$ Cap Neurovit 1 cap daily and Acceclofenac 200mgwith Rabiprazol 20mg SR capsule daily) shows excellent therapeutic response in all the cases. Self bloof intramuscular induces antibody aginst $R A$ antigen resulting in immunosuppression and competitive inhibition of immune body formation restricting joint inflammation, degenerative changes of the joint and facilitate better joint mobility and ultimately improve quality of life .
\end{abstract}

Keywords: Auto immune, Rh factor, Degeneration, Antigen, Antibody, DMARD, neurotonic, quality of life

\section{INTRODUCTION}

Rheumatoid arthritis ,an auto immune disease causing degenerative joint changes resulting in deformity and movement restriction with agonizing pain ful movement at joints, thus make the person crippled or handicap even for their routine activities ${ }^{1,2}$.. This affect $0.5 \%-1 \%$ people of the developed world and 5-50 cases every lakh population in added every year. Onset during middle age is more common and women are affected 2.5 times more than men ${ }^{1}$. The pain associated with Ra is induced at the site of inflammation and termed as Nociceptive than neuropathic. Glycan (Oligo saccharide ) alteration causes joint inflammation. Plasma cell derived from $\mathrm{B}$ lymphocytes produces $\mathrm{Rh}$ factor,ACPA of the IgG and IgM type in large quantity. ${ }^{2}$ The goal of treatment is to alleviate pain, decrease inflammation and improve functional capabilities. Commonly used therapeutics constitutes Analgesic, Steroid and disease modifying anti rheumatoid drugs (DMARDs) ${ }^{3,4}$ fail to ensure cure or complete symptomatic relief . Considering its auto immune pathogenesis, a biological regime constituting Self blood $2 \mathrm{ml}$ with Betamethasone been evaluated in non diabetic rheumatoid arthritis cases.

\section{Material \& Methods}

Patients of rheumatoid arthritis diagnosed on the basis of clinical presentation and confirmed by serological \& radiological evaluation, non responsive to the conventional anti rheumatoid regimes were selected to evaluate the clinical efficacy and safety profile of Self blood with Betamethasone intramuscular in non diabetic or controlled diabetic patients. 
Each selected patients were interrogated for the history of disease, therapeutics consumed and their clinical response and were examined thoroughly to evaluate the quality of life and movement at the joints.

All patients were serologically evaluated for Rheumatoid factor, C-reactive protein, Anti nuclear antibody (ANA), Renal function test, hepatic enzymes, hematological values and radiological examination for joint status. In addition each patients were assessed for pre and post therapy (after 6 month) for hematological and hepato renal parameters.

Based on the therapeutic status and clinical presentation, patients were classified in to the following grade of severity ${ }^{5}$

\section{Severity Grade}

Grade I

Grade II

Grade III

Grade IV

\section{Characteristics}

Patient suffering from less than 2 yrs without any joint deformity and restricted movement, not taken DMARD

Patients suffering $>2$ yrs but less than 5 yrs,taken anti arthritic, steroid, parenteral Calcium, vitamin D3, improves pain

Not taken DMARD

Patient suffering from $>5$ yrs taken all the therapeutics including DMARDs, present with joint deformity and handicap

Patient suffering from $>10$ yrs, handicap due to joint deformity, taken all the therapeutics without any relief

Each selected patients were advocated a regime constituting -

$>$ Self blood $2 \mathrm{ml}$ with Inj Betamethasone $1 \mathrm{ml}$ intramuscular every $4^{\text {th }}$ day till patient show improvement.

$>$ Inj. Calcium Gluconate $10 \mathrm{ml}$ every $21^{\text {st }}$ day intravenous very slow

$>$ Inj Methyl Cobalamine with B complex every $4^{\text {th }}$ day slow intravenously

$>$ Cap. Vitamin $\mathrm{D}_{3} 60 \mathrm{~K}, 1$ cap every week,

$>$ Cap Neurovit, a neuro regulator, 1 cap daiy

$>$ Tab Aceclofenac 200mg SR with Rabiprazol $20 \mathrm{mg} 1$ tab daily

Avoid non vegetarian diet

Each patients were given a follow up card with facility to enter relief and adversity (if any)

Follow up Card

\begin{tabular}{|c|c|c|c|c|c|c|c|c|c|c|c|}
\hline \multirow[t]{2}{*}{ Particulars } & \multicolumn{11}{|c|}{ Duration in Weeks } \\
\hline & $1^{\text {st }}$ & $2^{\text {nd }}$ & $3^{\text {rd }}$ & $4^{\text {th }}$ & $5^{\text {th }}$ & $6^{\text {th }}$ & $7^{\text {th }}$ & $8^{\text {th }}$ & $9^{\text {th }}$ & $10^{\text {th }}$ & $11^{\text {th }}$ \\
\hline \multicolumn{12}{|c|}{ Relief in joint } \\
\hline \multicolumn{12}{|c|}{ pain } \\
\hline \multicolumn{12}{|l|}{ swelling } \\
\hline \multicolumn{12}{|l|}{ movement } \\
\hline \multicolumn{12}{|c|}{ Quality of life } \\
\hline \multicolumn{12}{|l|}{ Agony } \\
\hline \multicolumn{12}{|l|}{ General - } \\
\hline \multicolumn{12}{|l|}{ condition } \\
\hline \multicolumn{12}{|l|}{ Urine output } \\
\hline \multicolumn{12}{|l|}{ Tingling \& } \\
\hline \multicolumn{12}{|l|}{ Numbness } \\
\hline Muscle bulk & & & & & & & & & & & \\
\hline
\end{tabular}

After 3 months of therapy patients hematology, hepatic enzymes and renal function parameters were repeated to adjudge the safety profile.

\section{ObServations}

Among the selected 210 patients of non diabetic non hypertensive RA, 60 were male and 150 were female of age group 35-55 yrs. (Table -1), Pie diagram showing sex wise composition. 
Table1. Shows distribution of patients as per age and sex

\begin{tabular}{|llll|}
\hline Age group A & \multicolumn{3}{c|}{ Number of patients } \\
(in yrs) & Male & Female & Total \\
$35-40$ & 24 & 52 & 76 \\
$40-45$ & 16 & 38 & 54 \\
$45-50$ & 11 & 34 & 45 \\
$50-55$ & 09 & 26 & 35 \\
\hline
\end{tabular}

Pie diagram showing sex wise composition:

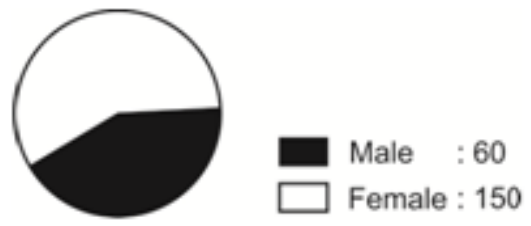

Common presentation i.e.- agonizing joint pain, swelling of the joint and physical in capabilities were common among all whereas 190 cases had wasting and worst and poor quality of life in 70 and 40 cases respectively (Table -2)

Table2. Showing Presenting Complaints

\begin{tabular}{|lc|}
\hline Presenting complaints & Number of patients \\
Agonising joint pain: & 210 \\
Swelling of the joint: & 210 \\
Wasting: & 190 \\
Physical incapabilities: & 210 \\
Quality of life: & \\
Poor- & 040 \\
Moderate & 100 \\
Worse & 070 \\
\hline
\end{tabular}

$51.9 \%$ patients were suffering with the presentation for $>5 \mathrm{yrs}$ where as only $1.9 \%$ were suffering from $\leq 1$ yr (Table-3)

Table3. Distribution of Patients as per duration of illness

\begin{tabular}{|ll|}
\hline $\begin{array}{l}\text { Duration of illness } \\
\text { (in yrs) }\end{array}$ & Number of patients \\
$<1 \mathrm{yr}$ & 04 \\
$1-2 \mathrm{yr}$ & 07 \\
$2-3 \mathrm{yr}$ & 08 \\
$3-4 \mathrm{yr}$ & 09 \\
$4-5 \mathrm{yr}$ & 73 \\
$>5 \mathrm{yr}$ & 109 \\
\hline
\end{tabular}

Majority (64.8\%) have taken all the available anti rheumatoid treatment without any relief while 2patients $(0.95 \%)$ have not taken Disease modifying anti eheumatoid drugs but only anti arthritic and neurovitamins . (Table -4)

Table4. Distribution of patients as per their therapeutic status

\begin{tabular}{|ll|}
\hline Therapeutics taken & Number of patients \\
Anti arthritic analgesic + & \\
Neuro vitamin supplement & 02 \\
Antiarthritic analgesic+ parenteral & \\
Calcium +Vitamin D3+Steroid & 08 \\
Anti arthritic analgesic +parenteral & \\
Calcium supplement+ Vitamin D3 & \\
+ Disease modifying anti rheum- & \\
atoid drug supplement & 74 \\
All the above & 136 \\
\hline
\end{tabular}

All selected patients reveal raised $\mathrm{C}$ reactive protein, Rheumatoid factor, Erythrocyte sedimentation rate and radiological appearance shows joint deformity (Table- 5) 
Table5. Bar diagram showing distribution of patients as per clinical severity

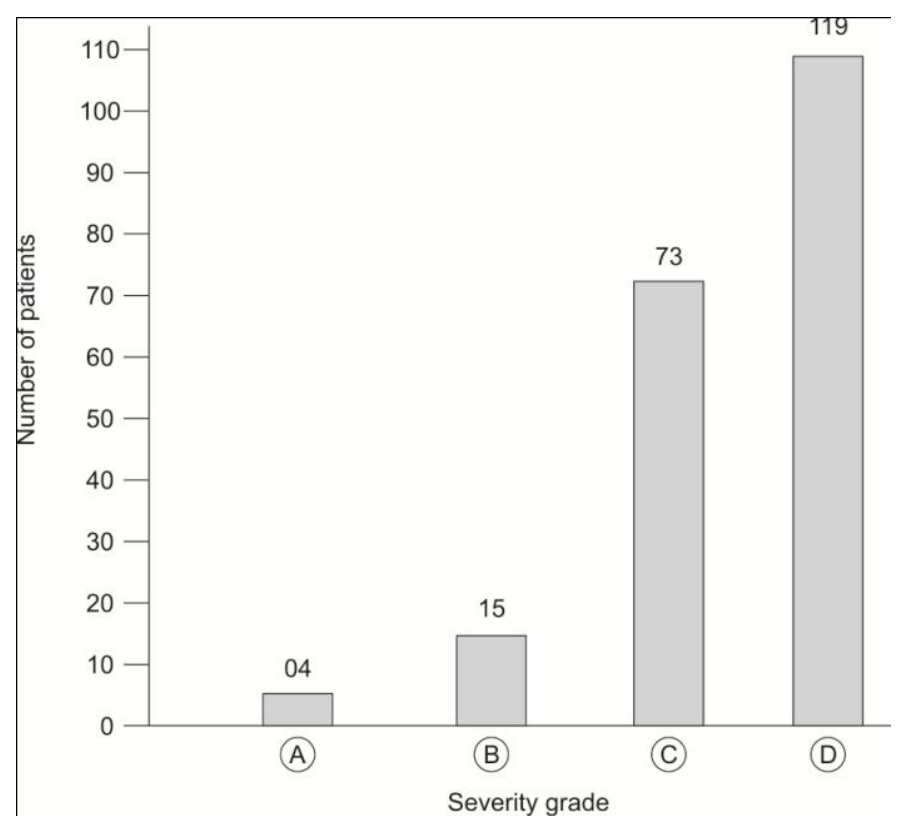

All cases had onset of pain relief and decline in joint swelling by $15^{\text {th }}$ day of therapy ,all cases of illness of $<1 \mathrm{yr}$ duration shows complete relief of all the presentation by $3^{\text {rd }}$ month while all cases illness of duration $>5$ yrs taken 9 months in complete normalcy of joint movement and texture.

No patient shows any alteration in pre therapy hematological, hepatic and renal index assessed on complete relief of presentation.

All patients irrespective of their duration of illness, severity grades achieved excellent clinical response while 20 patients of grade IV severity and illness duration $>5$ yrs shows grade II response

No cases had any worsening of presentation but had improved quality of life.

Table6. Showing serological and radiological status of the selected patients.

\begin{tabular}{|c|c|}
\hline Particulars & Number of patients \\
\hline \multicolumn{2}{|l|}{ Serological: } \\
\hline $\mathrm{Rh}$ factor raised & 210 \\
\hline $\mathrm{C}$ reactive protein increased & 210 \\
\hline Anti nuclear Antibody increased & 210 \\
\hline \multicolumn{2}{|l|}{ Renal Parameters: } \\
\hline \multicolumn{2}{|l|}{ Blood urea } \\
\hline$\leq 30 \mathrm{mg}$ & 210 \\
\hline \multicolumn{2}{|l|}{ Serum creatinine } \\
\hline$\leq 1.5 \mathrm{mg} \%$ & 210 \\
\hline \multicolumn{2}{|l|}{ Hepatic Enzymes: } \\
\hline \multicolumn{2}{|l|}{ SGOT: } \\
\hline$>35 \mathrm{IU}$ & 000 \\
\hline$<35 \mathrm{IU}$ & 210 \\
\hline \multicolumn{2}{|l|}{ SGPT } \\
\hline$>30 \mathrm{IU}$ & 000 \\
\hline$<30 \mathrm{IU}$ & 210 \\
\hline \multicolumn{2}{|l|}{ Hematlogy: } \\
\hline \multicolumn{2}{|l|}{ Hemoglobin } \\
\hline$\leq 10 \mathrm{gm} \%$ & 104 \\
\hline$>10 \mathrm{gm} \%$ & 106 \\
\hline \multicolumn{2}{|l|}{ Radiological: } \\
\hline Joint destruction & 209 \\
\hline
\end{tabular}


Table7. Outcome of the study

\begin{tabular}{|c|c|}
\hline Clinical presentation & Number of Patients \\
\hline Pain relief & 210 \\
\hline Joint swelling & 210 \\
\hline Mobility: & \\
\hline Normal & 210 \\
\hline Quality of life & \\
\hline Improved & 210 \\
\hline $\begin{array}{l}\text { Post therapy; } \\
\text { Rh factor titre }\end{array}$ & \\
\hline ANA & 210 \\
\hline $\begin{array}{r}\text { Decreased } \\
\mathrm{C} \text { reactive protein }\end{array}$ & 210 \\
\hline $\begin{array}{l}\text { Decreased } \\
\text { Hemoglobin }\end{array}$ & 210 \\
\hline $\begin{array}{l}\quad \text { Improved }(>12 \mathrm{gm} \%) \\
\text { Heapatic enzymes } \\
\text { SGOT; }\end{array}$ & 210 \\
\hline SGPT $<35 \mathrm{IU}$ & 210 \\
\hline$<30 \mathrm{IU}$ & 210 \\
\hline
\end{tabular}

\section{Discussion}

Rheumatoid arthritis, an auto immune disorder is due to abnormal immune response of the body against substances and body tissues which causes thickness of joint capsule, affects under lying bones and cartilage, tendon teethering, erosion and destruction of joint surface leading to impaired movement and deformity ${ }^{5}$. Considering the ethics- any protein entering the body ,body produces antibody against the particular protein ,hence Self blood constituting the antigen for Rheumatoid arthritis when enters the body produces antibody to counter the effect of the antigen thus check immune induced inflammation of the joint and promote natural healing. Parentral Calcium supplementation helps bony regeneration, vitamin D3 help in bony reconstruction and anti arthritic analgesic relieves agonizing pain.

\section{Conclusion}

Self blood $2 \mathrm{ml}$ with Betamethasone $4 \mathrm{mg}(1 \mathrm{ml})$ intramuscular every $4^{\text {th }}$ day proves worth in improving clinical presentation and quality of life even in RA patients non responsive to DMARDs

\section{REFERENCES}

[1] American College of Rheumatology Subcommittee on Rheumatoid Arthritis Guidelines. Guidelines for the management of rheumatoid arthritis: 2002 Update. Arthritis Rheum 2002; $46: 328$

[2] Geusens P, Wouters C, Nijs J, et al. Long-term effect of omega-3 fatty acid supplementation in active rheumatoid arthritis. A 12-month, double-blind, controlled study. Arthritis Rheum 1994; 37:824.

[3] PJW Venables, Rheumatoid arthritis treatment (Beyond the Basics, Kennedy Institute, Oxford University

[4] Rheumatoid arthritis management, Arthritis Foundation

[5] Rheumatoid arthritis, Medical News Today 


\section{AUTHORS' BIOGRAPHY}

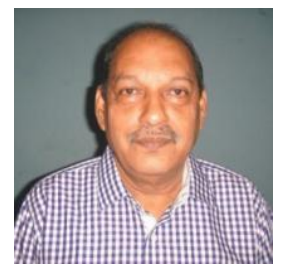

Avinash Shankar, a postgraduate in internal medicine and super specialized in endocrinology and Metabolism fromk AIIMS Delhi, LLB (Magadh University), MBA(HA) Alaggapa university and $\mathrm{PhD}$ in Ayurveda from Mumbai University, MD in Acupuncture (Hongkong); a dedicated clinician ,published more than 300 papers in original in various national and international medical journal in various aspect of medical sciences, presented papers at various national and international medical conferences in India and abroad, Chaired various National and International medical conferences of various disciplines ,editor and editorial board members of various National and International journal of repute, authors of various medical literature and books, conceptualized CME program for grass root health workers for better implementation of health care at rural level ,Devised modern therapeutic measures for various dreaded disease and drug formulation for medicare to ensure quality health care with dedication, determination and dignity. President of Organization like Leucoderma Foundation of India, Epilepsy forum of India, Diabeties Research Society, Chairman Centre For Indigenous Medicine \& Research, Heading an NGO working for creating awareness regarding various disease. Authored books like - Hand Book Of Poisoning, Synopsis of Treatment, Synopsis of Diagnosis, Biohealing, Pharmacological Basis of Indigenous Therapeutics, Holistic Pediatrics, Writing Books for Undergraduate and Postgraduate medical studies.

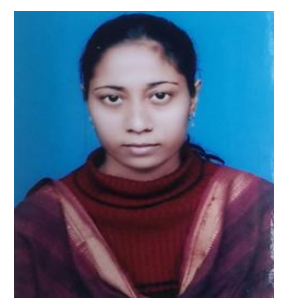

Dr Farhat Jabeen, A medical graduate working as project officer in the department of critical medicine and monitored burn management, she worked in the various department and monitored research work on Diabetes mellitus ,thyroid Neurological disorder and toxicology, She has published papers as co author and investigator in various national \& International medical journals. Presently working as Medical officer in the Government Medical services and conducting survey of School going children for various congenital disorders 